Ministry of Economv and Finance

Department of the Treasurv

Analisi e Programmazione

Economico Finanziaria

\title{
The Beveridge Curve in the OECD Before and After the Great Recession
}

Sergio Destefanis, Giuseppe Mastromatteo

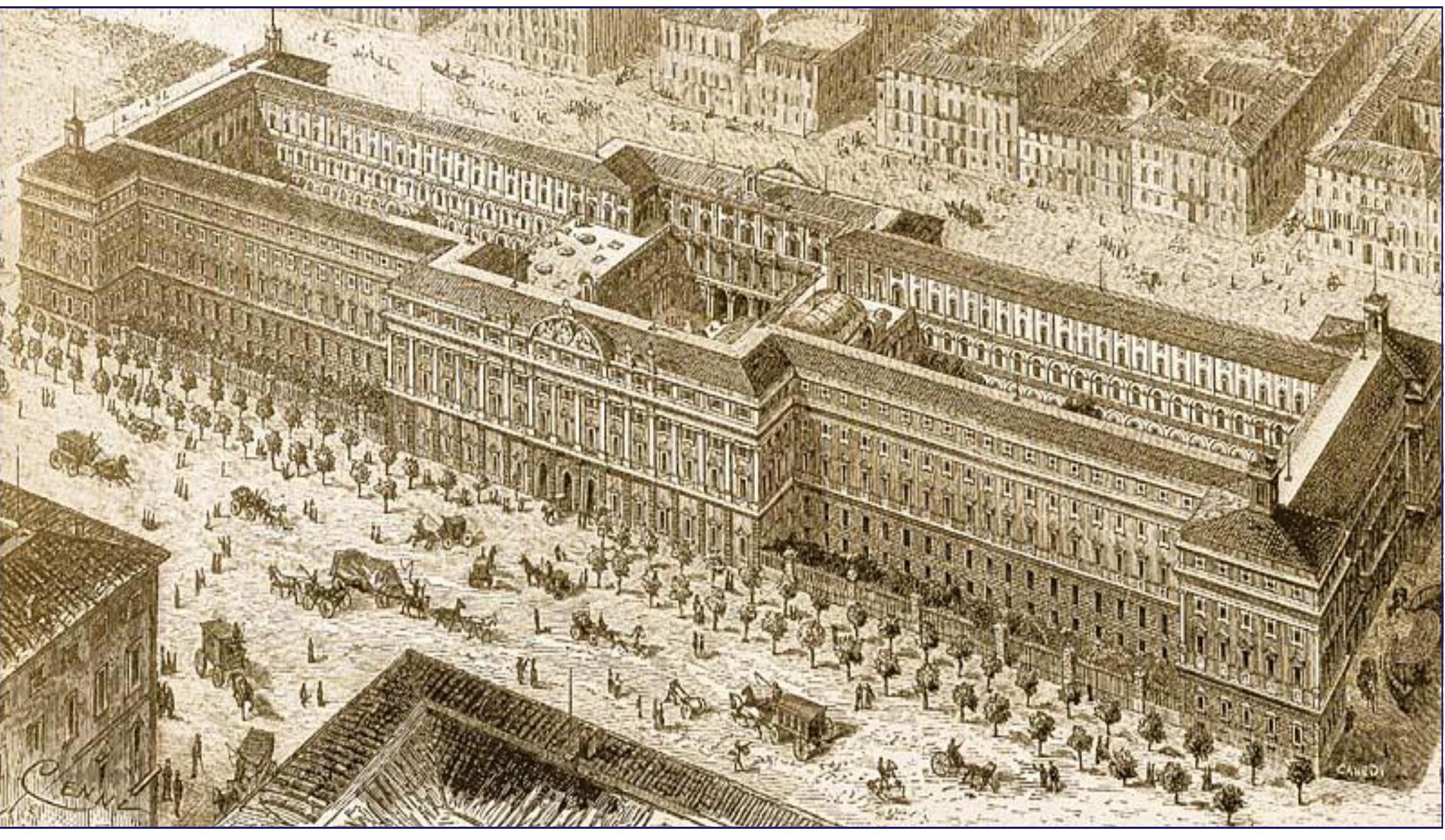




\section{Working Papers}

The working paper series promotes the dissemination of economic research produced in the Department of the Treasury (DT) of the Italian Ministry of Economy and Finance (MEF) or presented by external economists on the occasion of seminars organized by MEF on topics of institutional interest to the DT, with the aim of stimulating comments and suggestions.

The views expressed in the working papers are those of the authors and do not necessarily reflect those of the MEF and the DT.

\section{(C) Copyright:}

2016, Sergio Destefanis, Giuseppe Mastromatteo.

The document can be downloaded from the Website www.dt.tesoro.it and freely used, providing that its source and author(s) are quoted. 


\title{
The Beveridge Curve in the OECD Before and After the Great Recession
}

\author{
Sergio Destefanis (*), Giuseppe Mastromatteo $\left({ }^{* *}\right)$
}

\begin{abstract}
This paper analyses the Beveridge Curve across nine OECD countries from 1985 to 2012. Besides allowing for some customary labour-market institutions, we assess the role of various kinds of structural factors (technological progress, globalisation, oil prices) and of the current recession on the Curve. Significant institutional variables include unemployment benefits, the tax wedge, active labour-market policies and employment protection legislation (the latter improving the unemployment-vacancies trade-off). Technological progress (R\&D intensity) shifts the Curve outwards, producing evidence in support of a creative destruction effect. Globalisation and unfavourable oil price shocks also shift the Curve outwards. Structural relationships seem to be stable throughout the 2008-2012 period, suggesting that the Great Recession mainly implied moves along the Curve.
\end{abstract}

JEL Classification: E24, J20, F60, O40.

Keywords: Unemployment, vacancies, globalisation, creative destruction, labour-market policies.

\footnotetext{
* CSEF, DISES - Università di Salerno, Via Giovanni Paolo II, 132 - 84084 Fisciano (SA) - ITALY. e-m: destefanis@unisa.it; tel.: +39089962204.

** Istituto di Politica Economica - Università Cattolica del Sacro Cuore, Milan.
}

The authors would like to thank an anonymous referee, Luigi Campiglio, Nino Caroleo, Ron Oaxaca, Marco Vivarelli and other participants at seminars at the Catholic University of Milan and Piacenza, the Parthenope University of Naples and the University of Santiago de Compostela for useful comments on a previous draft. We also thank Kazuhiko Hayakawa for useful discussions about estimation issues. The usual disclaimer applies. 


\section{CONTENTS}

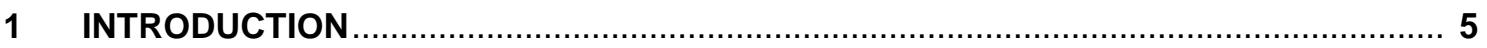

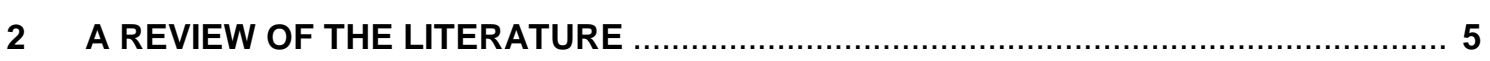

3 EMPIRICAL SPECIFICATION AND DATA

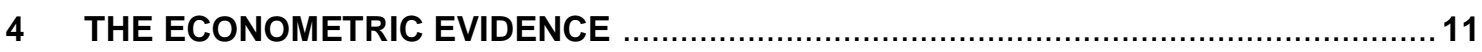

5 CONCLUDING REMARKS

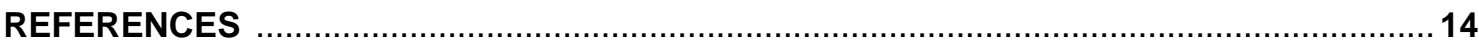

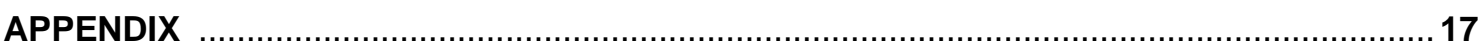

LEGEND OF TABLES

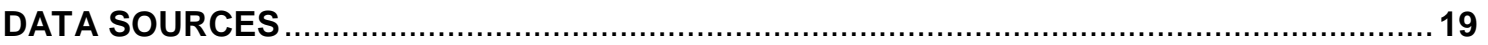

\section{FIGURES and TABLES}

Table 1. Expected shifts of the Beveridge Curve: institutional and structural variables .......17

Table 2. The main variables - some descriptive statistics............................................... 17

Table 3. Globalisation - ratio of total manufacturing imports from non-OECD countries to value added in_manufacturing (see text); percentage values for selected years ... 17

Table 4. Technological progress - ratio of R\&D expenditure in manufacturing to value added in manufacturing (see text); percentage values for selected years ............. 17

Fig. 1 The Beveridge Curve across the OECD, 1980-2012 ........................................... 18

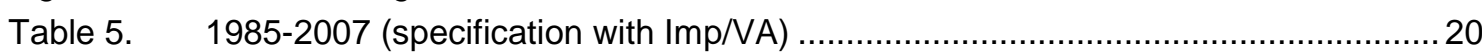

Table 6. 1985-2007 (specification with KOF index for actual economic flows) .....................21

Table 7. $\quad 1985-2007$ (specification with KOF overall index) .................................................. 21

Table 8. 1985-2012 (specification with Imp/VA). No crisis-specific dummies ........................ 22

Table 9. 1985-2012 (specification with KOF index for actual economic flows).

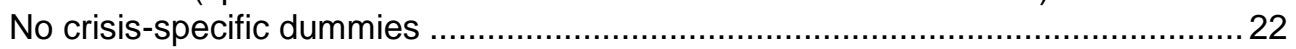

Table 10. 1985-2012 (specification with KOF overall index). No crisis-specific dummies .....23

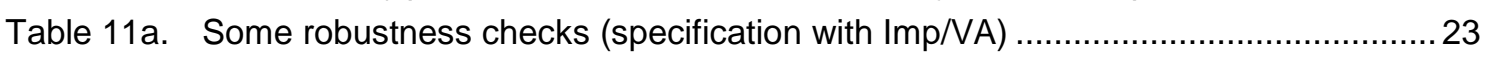

Table 11b. Some robustness checks (specification with Imp/VA) ...........................................24

Table $12^{\circ}$ The Main Results: 1985-2007 (Eq. 1 - Baseline specification with different measures of globalisation) .......................................................................... 24

Table 12b. The Main Results: 1985-2007 (Eq. 1 - Various specifications with Imp/VA) .........24

Table 13a. The Main Results: 1985-2012. (Eq. 1 - Baseline specification with different

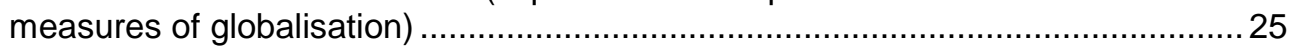

Table 13b. The Main Results: 1985-2007 (Eq. 1 - Various specifications with Imp/VA) .........25

Table 14. The Impact of the Crisis: Eqs. $2 b$ and $2 c$ - Baseline specification with Imp/VA. (Standalone slope dummy for each institutional variable in turn in Eq. 2c) ............25

Table 15. The Impact of the Crisis: Eq. 2d - Baseline specification with Imp/VA. (Standalone slope dummy for each institutional variable in turn) 


\section{INTRODUCTION}

The aim of this paper is to appraise the evolution of the Beveridge Curve across nine OECD countries from 1985 to 2012 (our choice of countries essentially depends on the quality of available data; we come back to this in Section 3). Drawing inspiration from Nickell et al. (2003) our analysis sheds light upon a wide spectrum of labour-market policies and institutions. In recent years the Beveridge Curve has been the object of renewed analytical attention (see for instance Bonthuis et al., 2013; Hobijn and Şahin, 2013; Sell and Reinisch, 2013; Arpaia et al., 2014). Yet we are not aware of papers dealing with the impact of a large set of policies and institutions before and after the recent recession, which is believed to have brought about longlasting changes in the world economy. Some papers assess whether the Beveridge Curve shifted outwards during the recession, but fairly little is said in the literature about the connections between this (eventual) shift and labour institutions and policies. Besides, few economists would deny that technological progress and globalisation have been among the fundamental socio-economic phenomena of this turn of century. However, very few works considered the role of technological progress as a potential shift factor for the Beveridge Curve, with no unanimity about the sign of its impact. Similarly, there is virtually no direct evidence about the impact of globalisation on the unemployment-vacancies trade-off. In this paper we extensively allow for the impact of technological progress and globalisation upon the Curve. In the same spirit, we include among the potential shifters of the Curve a hitherto neglected factor, real oil prices, whose relevance for macroeconomic fluctuations has no need to be justified.

The paper has the following structure. In Section 2 we examine some empirical literature on OECD countries providing motivation to our study and some focus for the role of the current crisis in this context. In Section 3 we present the empirical specification and the data. The results are commented in Section 4, whereas Section 5 contains some concluding remarks.

\section{A REVIEW OF THE LITERATURE}

Nickell et al. (2003) analyse empirically the unemployment patterns in twenty OECD countries from the 1960s to the mid-1990s, through a detailed study of changes in real wages and unemployment, as well as shifts in the Beveridge Curve. They want to ascertain if these shifts can be explained by changes in the labour market institutions (unemployment benefit replacement ratio and duration index, bargaining coordination, collective bargaining coverage, union density, employment protection legislation, labour taxes, homeownership rate). They find that, as expected, union density, unemployment benefit duration and owner occupation shift the Curve outwards (worsening the trade-off). On the other hand, stricter employment protection shift it inwards (improving the trade-off), possibly because they lead to an increased professionalisation of the personnel function within firms. We shall come back in Section 3 to the expected role for institutional variables. What is however remarkable from our point of view is that, while Nickell et al. believe that some structural factors (trend productivity, or real import prices) are relevant in affecting matching between labour supply and demand, they do not include in the Beveridge Curve estimates any such variables. No theoretical or empirical 
justification is given for this, providing a strong motivation for the inclusion of these factors in our analysis.

In more recent years the Beveridge Curve has received some analytical attention, especially since the inception of the Great Recession. This crisis is widely believed to have brought about long-lasting changes in the world economy. In terms of the Beveridge Curve there may have been an outward shift of the curve because hysteresis effects (a deterioration of human capital or of the search ability of the unemployed, a negative perception of the long-term unemployed on the part of potential employers), or a change in the skill demand-mix (low-skilled workers brought in the labour market by an added worker effect') have increased mismatch in the labour market. There may also be other channels through which the crisis has changed matching efficiency: a higher availability of unemployment benefits can have a detrimental effect on matching efficiency, while stronger active labour market policies may actually increase this efficiency.

Contributions to the recent literature include Arpaia and Curci (2010) who find that, for European labour markets, there have been moves along rather than shifts of the Beveridge Curve. Yet, looking ahead, they surmise that the matching efficiency may decrease in countries where structural reallocation was already strong in 2008 and 2009 (Czech Republic, Denmark, Ireland, Lithuania, the Netherlands, Slovenia, Slovak Republic). On the other hand Elsby et al. (2010) find an outward shift in the Beveridge curve since early 2009 for the US labour market. They believe that the substantial extension of the potential duration of unemployment benefits may have moderately contributed to this outward shift.

Both the above contributions are based on careful data reconstruction and eyeballing of Beveridge Curve (or matching function) charts, much as Diamond and Şahin (2014), who provide an historical analysis of the Beveridge Curve in the US. They find that the Beveridge Curve has moved outward seven times in post-war recessions. But three times out of seven (in the 1960s, 1980s and 1990s), the unemployment rate went back to its previous lows, suggesting that the Curve shifted out only temporarily and that no structural change in matching efficiency had occurred.

Hobijn and Şahin (2013) provide another analysis centred on data reconstruction and descriptive tools. These authors however relate more explicitly the evolution of the Beveridge Curve to its potential shifters. They first discuss the shift in the Beveridge curve in the US after the Great Recession and argue that skill mismatch and the extended coverage of unemployment benefits have had a significant role in this shift. Then they extend their analysis to other OECD countries for which data on vacancies and employment by job tenure are available. They find an outward shift for four other countries (out of fourteen): Portugal, Spain, UK and Sweden. The shift is ascribed to similar mismatch factors as in the US in the first three countries and to labour market reforms (predating the Great Recession) in Sweden. The other countries, i.e. Australia, Austria, Belgium, France, Germany, Japan, the Netherlands, Norway, and Switzerland, seem to stay close to their pre-2008 Curve.

Bonthuis et al. (2013) relying mainly on graphical analysis, find considerably heterogeneous behaviour in the Euro-area Beveridge Curves since the beginning of the crisis. A sizeable outward shift shows up for France and Spain, while Germany exhibits an inward shift (possibly

\footnotetext{
${ }^{1}$ On the other hand a discouraged worker effect, pushing off the market mainly marginal workers, may work in the opposite direction.
} 
following up from earlier structural reforms). In a second step, estimated Beveridge curve shifts are used as dependent variables in a probit model, in order to shed light upon the drivers of the shifts. This econometric exercise highlights the importance of sectoral employment losses (mainly in construction) as shifters. Labour force age and, to a lesser extent, skills, are also associated with the probability of a shift. Labour-market institutions are on the other hand found to be largely insignificant.

Sell and Reinisch (2014) estimate a Beveridge Curve (along with a New Keynesian Phillips curve and a "third curve" relating the vacancy ratio and the inflation rate) on quarterly data from eleven European countries for the 2008-2010 period. They find favourable evidence for all three relationships, but do not delve into the role of labour market institutions (besides, by construction, their analysis cannot shed any light on shifts of the Curve vis-à-vis the period before 2008).

Arpaia et al. (2014) estimate econometrically the Beveridge curve in EU countries, attempting to isolate temporary changes from structural changes in labour-market matching efficiency. Again a considerable degree of cross-country heterogeneity shows up. Matching efficiency appears to worsen in the euro-area countries mostly hit by the debt crisis, and improves in other countries (notably Germany). Secondly, the main drivers of job matching efficiency are analysed through fixed-effects panel regressions. Lengthier unemployment spells, as well as skill and sectoral mismatches, appear to be significantly correlated with lower matching efficiency. Some role is also found for labour-market institutions. Active labour market policies favour matching efficiency, while the opposite effect is found (less pervasively) for more generous unemployment benefits.

Both Bonthuis et al. (2013) and Arpaia et al. (2014) rely on a two-step approach, potentially prone to misspecification, and consider only a limited set of institutional variables (basically employment protection legislation, unemployment benefits and active labour market policies).

In the papers considered above, mismatch has often been - rightly - referred to as one of the main influences behind shifts in the Beveridge Curve, and sometimes its empirical counterparts ${ }^{2}$ have been utilised in econometric estimation. However, these traditional mismatch measures, being based on employment indicators, make any relationship between them and the Curve liable to a charge of spuriousness. This point is dealt at length in Entorf (2003; it is perhaps not surprising that Nickell et al., 2003, being well grounded in this early tradition, do not make any use of these indicators). Here we endeavour a solution to this problem, by taking into account some exogenous determinants of labour-market mismatch.

Few economists would deny that technological progress and globalisation have been among the fundamental socio-economic phenomena of this turn of century. They may be expected to impact heavily on the matching of labour supply and demand across the world (and in fact there has been substantial attention paid to their role in shaping wage and income inequality). Yet in the literature related to the Beveridge Curve only very few contributions have considered these variables. We believe this is an important gap. Making full allowance for technological progress and globalisation, two of the main potential determinants of mismatch, should bring in the estimates relevant information about this phenomenon without incurring in any spuriousness charge.

\footnotetext{
2 They are basically measures of dispersion of age-, area-, skill- or sector-specific employment; in the past, unemployment and vacancies have also been taken beside employment.
} 
In the conventional matching model with technological change (Pissarides, 1990; Mortensen and Pissarides, 1998), a higher rate of growth implies a higher present value of jobs, which spurs the recruiting activity and raises the job finding rate of unemployed workers. This so-called capitalisation effect should increase the willingness of employers to open new positions, shifting the Beveridge Curve inwards. On the contrary, Aghion and Howitt (1994) propose a creative-destruction (Schumpeterian) model, whose underlying intuition is that growth has a reallocative aspect that the previous model ignores: faster technological change is accompanied by faster obsolescence of skills and technologies, hence, more intense labour turnover and higher frictional unemployment. This should worsen matching efficiency, regardless of search intensity, which shifts the Beveridge Curve outwards. ${ }^{3}$ Hence, there is no unanimity about the expected impact of technological progress on the Curve.

The influence of increasing international interdependence and integration on labour market matching has never been embodied in formal economic models. The IMF and the OECD (see e.g. IMF, 1996, and OECD, 1997) have shared the opinion that globalisation, far from being a source of unemployment, can be used in a strategy for better growth and employment. On the other hand, many critics of globalisation (ICFTU, 1996; Thorpe, 1997) have voiced the concern that this phenomenon has been associated with rising structural unemployment among lowskilled workers, mainly in the manufacturing sectors most exposed to international competition. According to Nickell and Bell (1995) and Song and Webster (2003), there is indeed some empirical evidence that the Beveridge Curve for unskilled workers has shifted outwards in recent years, due to increasing competition from low-wage countries. A corresponding outward shift in the aggregate Beveridge Curve should have also followed.

On the other hand, the impact of oil prices on the Beveridge Curve has received little, if any, attention in the literature. Yet oil prices are widely believed to be one of the dominant factors in the world economy (see e.g. Loungani 1986). Oil-price shocks are also believed to affect the capital-output ratio and the labour share in the OECD since 1970 (Bentolila and Saint-Paul 2003). By the same token, they ought to influence the skill demand-mix and matching efficiency (Ordóñez et al., 2011, provide a first attempt along these lines). Besides, oil prices are also an important determinant of induced technological progress (Kumar, 2008). We thus include among the potential shifters of the Curve also this hitherto neglected factor.

\section{EMPIRICAL SPECIFICATION AND DATA}

Following the discussion of the previous section, we believe that novel and interesting evidence about the Beveridge Curve can be obtained through a cross-country analysis allowing not only for a set of institutional variables traditional in this literature, but also for structural factors impacting upon the labour market, such as technological progress, globalisation and oil prices. We maintain that only within this set-up we can assess whether the Great Recession had a genuinely independent effect over the Beveridge Curve.

In selecting our institutional variables of interest, we mainly relied on Nickell et al. (2003)

\footnotetext{
${ }^{3}$ According to Postel-Vinay (2002) and Pissarides and Vallanti (2007), creative destruction could prevail in the short run, and the capitalisation effect in the long run. Pissarides and Vallanti (2007) stress that the creative-destruction effect is likely to occur when technology is mainly embodied in new jobs.
} 
and the following literature. We focused upon: a) unemployment benefits, whose generosity is supposed to negatively affect the willingness of unemployed to fill vacancies; $b$ ) employment protection legislation, whose overall impact is an empirical issue: on the one hand it tends to make firms more prudent about filling vacancies, which slows the speed at which the unemployed move into work; on the other hand, it often reduces involuntary separations and leads to higher efficiency of the personnel function within firm (Daniel and Stilgoe, 1978); consequently it reduces inflows into unemployment; c) the total tax wedge (including the employment tax, the direct tax and the indirect tax rate), supposed to discourage search for both unemployed and firms; d) active labour market policies, which are supposed to enhance matching efficiency (Nickell et al., 2003, only mention this variable, which is actually utilised by Arpaia et al., 2014); e) union density and bargaining coordination: trade union power in wage setting is likely to decrease the willingness of employers to open new positions, but highly coordinated bargaining may completely offset this negative impact (see e.g. Nickell and Layard, 1999, or Booth et al., 2000); f) minimum statutory wages (more precisely, the relationship between minimum wage and a measure of mean or median wage), on the one hand discouraging employers from opening new positions, while on the other hand eliciting more strenuous search from a share of the unemployed. ${ }^{4}$ We recapitulate in Table 1 (all tables are in the Appendix) the main predictions that can be drawn about institutional and structural variables.

Our baseline specification is a Cobb-Douglas dynamic specification of the following Beveridge Curve:

$$
\mathrm{ur}_{i t}=f\left(\mathrm{vr}_{i t}, \mathrm{glob}_{i t}, \mathrm{tp}_{i t}, \operatorname{roilp}_{i t}, \mathrm{Z}_{i t}, \mathrm{a}_{t}, \mathrm{a}_{i}\right)
$$

where $i=1, \ldots, \mathrm{N}$ stands for the country, and $t=1, \ldots, \mathrm{T}$ stands for the time period (year), $\mathrm{ur}_{i t}$ is unemployment rate, $\mathrm{vr}_{i t}$ the vacancy rate, $\mathrm{glob}_{i t}$ a measure of globalisation index, $\operatorname{tp}_{i t} \mathrm{a}$ measure of technical progress, roilp $i t$ real oil prices (deflated by consumer price indexes). All these variables are taken in natural logs. $Z_{i t}$ is the vector of institutional variables expected to influence matching efficiency; at and $a_{i}$ are vectors of year - and country - specific effects.

As is well known, the Beveridge Curve derives from a flow model of the labour market, under the equilibrium condition that separations (inflows into unemployment) are equal to hirings (outflows out of unemployment). In Eq. (1), hirings are determined by the relationship between vacancies and unemployment, while separations are assumed to be constant (a refinement of this hypothesis is that they are determined by the other variables included in (1)). Hence, our evidence is conditional on this hypothesis. We identify the Beveridge Curve and its shifts, only if the separation rate does not independently contribute to changes in the rate of unemployment. In Section 4, we provide some evidence consistent with this assumption.

We then attempt to gauge the role of the Great Recession through an augmented version of (1):

$$
\mathrm{ur}_{i t}=f\left(\mathrm{vr}_{i t}, \mathrm{glob}_{i t} \mathrm{tp}_{i t}, \operatorname{roilp}_{i t}, \mathrm{Z}_{i t}, f(\text { crisis }), \mathrm{a}_{t}, \mathrm{a}_{i}\right)
$$

\footnotetext{
${ }^{4}$ Nickell et al. (2003) refer to minimum wages, but do not include them in their estimates, on the ground that in OECD countries they are too high to impinge upon labour-market equilibrium. We did not feel entitled to assume away this variable, given the growing relevance of problems in the OECD youth labour market.
} 
There are various ways in which the effects of the Great Recession (crisis) can be modelled. The simplest is to include a period dummy (equal to 1 from 2008 onwards):

$$
\mathrm{ur}_{i t}=f\left(\mathrm{vr}_{i t}, \mathrm{glob}_{i t} \mathrm{tp}_{i t}, \text { roilp }_{i t}, \mathrm{Z}_{i t}, \text { crisis, } \mathrm{a}_{t}, \mathrm{a}_{i}\right)
$$

which would imply a common shift of the Beveridge Curve for all countries under scrutiny. Then, we can allow for country-specific period dummies (implying, of course, that the impact of the Great Recession differs across countries):

$$
\mathrm{ur}_{i t}=f\left(\mathrm{vr}_{i t}, \mathrm{glob}_{i t} \mathrm{tp}_{i t}, \text { roilp }_{i}, \mathrm{Z}_{i t}, \operatorname{crisis}_{i}, \mathrm{a}_{t}, \mathrm{a}_{i}\right)
$$

or for interaction effects among the crisis and labour-market institutions, highlighting whether the effect of these variables has weakened or increased during the Great Recession:

$$
\operatorname{ur}_{i t}=f\left(\mathrm{vr}_{i t}, \operatorname{glob}_{i t} \mathrm{tp}_{i t}, \operatorname{roilp}_{i t}, \mathrm{Z}_{i t}, \operatorname{crisis} * \mathrm{Z}_{i t}, \mathrm{a}_{t}, \mathrm{a}_{i}\right)
$$

Finally, we can allow for both country-specific period dummies and interaction effects:

$$
\mathrm{ur}_{i t}=f\left(\mathrm{vr}_{i t}, \text { glob }_{i t} \mathrm{tp}_{i t}, \operatorname{roilp}_{i t}, \mathrm{Z}_{i t}, \text { crisis } * \mathrm{Z}_{i t}, \operatorname{crisis}_{i}, \mathrm{a}_{t}, \mathrm{a}_{i}\right)
$$

We used three distinct proxies for the globalisation index. The preferred one, the same used in a different context by Koeniger et al. (2007), is the ratio of total manufacturing imports from non-OECD countries to manufacturing value added (both variables at current prices). In order to explore the role of other dimensions of globalisation, we also used the KOF index of actual economic flows (allowing for external trade, capital flows and outsourcing) and the KOF overall index of globalisation (Dreher, 2006).

We also follow Koeniger et al. (2007) by taking as our preferred measure of technological progress an index of R\&D intensity (the ratio of $R \& D$ expenditure over value added in the manufacturing sector, both variables at current prices). However, this measure is likely to emphasise the role of technology embodied in new jobs. Hence we also include in our estimates a Tornqvist index of total factor productivity. This TFP indicator also works as a catchall control (a feature reminiscent of the debate about the Solow residual). More information about the data and their sources is provided in the Appendix, where we also provide descriptive statistics for our variables (Tables 2 to 4$)^{5}$ and, as customary in the Beveridge Curve literature, a graphical representation of the vacancy-unemployment trade-off (Figure 1). Both the descriptive statistics and the graphical analysis show considerable heterogeneity in the countries under examination.

Unlike in many macroeconometric studies (including Nickell et al. 2003, and Koeniger et al., 2004), we did not restrict a priori the dynamic specification of our regressors. We followed Pissarides and Vallanti (2007) in introducing two lags for unemployment, while other variables initially entered (1) and (2) with a current and a (first-order) lagged value. We then proceeded to a general-to-specific search in order to find our preferred specifications.

\footnotetext{
${ }^{5}$ Given that our indicators of globalisation and technological progress are not very commonly found in the literature, we provide some extra information about them for selected years in Tables 3 and 4.
} 
We include in our analysis nine countries (Australia, Austria, Finland, Germany, Norway, Portugal, Sweden, Switzerland, United Kingdom) for which the OECD provides consistent vacancy data throughout the whole period of interest. In principle we wanted to apply our analysis to a wider set of countries, but our focus on parameter stability suggested to put a premium on data quality. In the end our sample is consistent both with good data quality and the representation of widely different labour-market institutions. As shall be clearer below, we focus mainly on a 23-year (1985-2007) and a 28-year period (1985-2012), but we shall also present some estimates with 1980 as initial year. There are missing data for some countries and years, and hence we have an unbalanced panel.

Our econometric approach is based upon the (one-step) system GMM estimator proposed in Blundell and Bond (1998). This estimator greatly reduces the finite sample bias in the case of highly persistent data. Bruno (2005) and Soto (2009) analysed through Monte Carlo simulations the properties of various GMM and other estimators when the number of individuals is small, as typical in cross-country studies. They find that the system GMM estimator typically has lower bias and higher efficiency than all other GMM estimators. Bruno (2005) also finds that system GMM performs well vis-à-vis Kiviet's corrected LSDV estimator, provided that the panel is unbalanced and data are highly persistent. Both conditions are met in the present case (statistics about the persistence properties of our variables are available upon request). Bruno also makes the often forgotten point that, unlike Kiviet's estimator, system GMM is also applicable in the presence of endogenous regressors. In past work (Destefanis and Mastromatteo, 2015) we have found that regressor endogeneity is likely to characterise the estimation of Beveridge Curves, strengthening the case for the adoption of system GMM.

In implementing this estimator, we consider the advice provided by Roodman (2009a, 2009b). More specifically: a) we used forward orthogonal deviations, computable for all periods except the last period even in the presence of gaps in the panel, in order to maximise sample size; b) we put every regressor into the instrument matrix: if a regressor is strictly exogenous, it is inserted as a single column; if it is predetermined but not strictly exogenous (such as our regressors), lags 1 and deeper are used in GMM-style; if it is endogenous, lags 2 and deeper are used in GMM-style; c) we paid attention in evaluating the results of autocorrelation and endogeneity tests, as a small number of cross-country observations makes Arellano-Bond test for autocorrelation less reliable and too many instruments weaken the power of the Hansen test to detect overidentification (for this reason, we limited the lags used in constructing the instrument set from the third up to the sixth and "collapsed" this set into a single column).

\section{THE ECONOMETRIC EVIDENCE}

All the estimated equations are reported in full in Tables 5-11 (a legend of the tables is provided in the Appendix). Evidence about the robustness of our specification can be seen in Table 11. In Table 11a, we present results for a version of (1) estimated back to 1980 without the ALMP indicator (available only since 1985). We also re-estimate (1) without Norway in the sample. Given the presence of oil prices among the regressors, some readers may feel that the inclusion of such a strong oil producer in the sample may unduly affect our evidence. In both cases we get results that do not appreciably differ vis-à-vis the other estimates. The oil price 
terms have perhaps the less stable coefficients, both without Norway and without ALMP, but the general impression is one of parameter stability. In Table 11b, we include in our estimates (again for various periods and specifications) a measure of the separation rate, defined as the ratio of inflow into unemployment to total employment (see on this Nickell et al., 2003). This variable is never significant, indicating that it does not independently contribute to changes in the rate of unemployment. Moreover, sign and significance of the other variables do not change vis-à-vis estimates not including the separation rate. Hence, we feel entitled to interpret evidence based on various specifications of Eq. (1) as providing information on the Beveridge Curve and its shifts. ${ }^{6}$

We consider in detail the main results from Eq. (1) for the 1985-2007 period, leaving for the time being the Great Recession out of the analysis, in Tables 12a-12b. We find a significant effect of the lagged index of $R \& D$ intensity, which shifts the curve outwards through a creative destruction effect. We tried various specifications for technological progress (with R\&D intensity and TFP, with R\&D only, with TFP only): TFP is never significant in our specifications of interest, although its inclusion seems to enhance the significance of $R \& D$ intensity. The globalisation index constructed along the lines of Koeniger et al. (2007) (dubbed Imp/VA in the following tables) is also significant with a positive sign. On the other hand, the KOF indexes of globalisation (much as they should allow for capital flows and outsourcing) were never significant. More than that, the specifications with the KOF indexes of globalisation consistently have a lower fit (as measured by the square of the correlation coefficient between the actual and predicted values for the unemployment rate; see Bloom et al., 2001) than estimates based upon $\operatorname{Imp} / V A$. Oil prices intervene mostly in terms of rates of change (although we did not restrict their current and first-order lagged coefficient): a positive oil price shock worsens the vacancy-unemployment trade-off.

Among the institutional variables, union density and bargaining coordination were never significant. They are not included in Tables 5-11 and are not commented upon any further (possibly these variables did not vary enough through time for the countries under scrutiny). EPL has the "wrong" sign, but, as already recalled, also Nickell et al. (2003) found this result. Unemployment benefit, the tax wedge and active labour market policies (over GDP) are significant and have the expected sign. The latter variable, however, is less consistently significant than the others across the various specifications (this fully comes out by looking at Tables 5-11). The ratio of minimum over median wage has a detrimental effect on the Curve (the discouragement effect upon employers being apparently stronger), but mostly intervenes in terms of rates of change.

Let us now turn to the Great Recession and its impact on the Curve. We first re-estimate Eq. (1) through 2008-2012, and examine the structural stability of its key parameters. The main results are summed up in Tables 13a-13b, which show parameters very close to their counterparts from Tables $12 a-12 b .{ }^{7}$ We conclude that Eq. (1) captures a specification of the

\footnotetext{
${ }^{6}$ Following the suggestion of an anonymous referee, we performed a further robustness check by adopting a different estimation method. We ran all the main estimates through the GMM technique suggested in Hayakawa (2009). Following correspondence with Kazuhiko Hayakawa, we could establish that our time series are sufficiently long as to ensure consistency of that estimation method. Results are available upon request and do not signal any relevant modification of our previous findings.

${ }^{7}$ Comparing Tables 5-7 with Tables 8-10 confirms this impression. This point is also validated by formal structural stability tests (Chow tests of parameter constancy) available upon request.
} 
Beveridge Curve that has not been fundamentally affected by the Great Recession. Yet, it is still true that there may be patterns of structural change across subsets of parameters (related e.g. to given countries or regressors). We explore this possibility by estimating Eqs. 2a-2d. In doing so, we restrict our attention to the baseline specification with $\operatorname{Imp} / \mathrm{VA}$ as a proxy of globalisation.

Estimation of Eq. (2a) confirms that there are no generalised patterns of structural change: the crisis dummy has very low coefficient size and significance $(0.0112$ with a t-ratio of 0.07 : this is validated by an insignificant Chow test of predictive accuracy, available upon request). It follows that the Great Recession has not lead to a common shift of the Beveridge Curve for all countries. Analysing Eqs. 2b-2d allows however the detection of more restricted patterns of structural change. Table 14 shows significant inward shifts for Austria and (especially) Germany, and an outward shift for Switzerland. Interestingly, no significant shift emerges for Portugal. This is somewhat surprising, given the large shift that can be eyeballed from Figure 1, and is indication that our baseline specification allows for a rather wide array of factors.

Focusing on the structural stability of parameters for labour-market institutions reveals that apparently the Great Recession weakens the detrimental effect of the tax wedge and strengthens the favourable effect of active labour market policies. No effect at all is discernible for other institutions (in particular for unemployment benefits, that were often mentioned in the recent literature). From the descriptive statistics in the Appendix, we can see that Germany and Austria have very high values for the tax wedge and (less so) for the ALMP indicator. In order to find out whether the above results are mainly driven by country- or institution-effects, we rely on Eq. $2 \mathrm{~d}$ where allowance is simultaneously made for country-specific (intercept) dummies plus a slope dummy for each institutional variable (in turn). The main results from this exercise are presented in Table 15. They reveal that, once allowance is made for the country-specific intercept dummies, very little indeed is gained by the inclusion of slope dummies for institutional variables (it is instructive in this sense to compare the rho"s of Tables 14 and 15).

All in all, our evidence decisively indicates that Great Recession did not lead either to a systematic shift in the Curve or to modifications of the effects of labour-market institutions. Once we allow for our structural and institutional factors, we find that the Great Recession has been characterised by moves along rather than shifts of the Beveridge Curve.

\section{CONCLUDING REMARKS}

In this paper we considered the economies of nine OECD countries from 1985 to 2012 in order to investigate the impact of various kinds of structural factors (technological progress, globalisation, oil prices) and of the Great Recession on the Curve.

We find that $R \& D$ intensity shifts the Curve outwards through a creative destruction effect. Also a globalisation index constructed along the lines of Koeniger et al. (2007) is consistently positive and significant. On the other hand, KOF indexes of globalisation were never significant. Oil prices intervene mostly in terms of rates of change, but a positive effect prevails. TFP is never significant in our specifications of interest.

Among the institutional variables, union density and bargaining coordination are never significant. EPL has the negative sign already found in Nickell et al. (2003). Unemployment benefit, the tax wedge and active labour market policies are significant with the expected sign. 
The ratio of minimum over median wage has a detrimental effect on the Curve, but mostly intervenes in terms of rates of change.

Our structural relationships seem to be very stable throughout the 2008-2012 period. Once we allow for our structural and institutional factors, we find that the Great Recession has been characterised by moves along rather than shifts of the Beveridge Curve. Yet, it may be interesting in future work to focus more closely on Austria, Germany and Switzerland. The widely different shifts occurring in the first two countries vis-à-vis the third one may contain some interesting policy lessons, especially if one considers that these countries are usually believed to have similar labour-market institutions. Other interesting future work may relate to the disaggregation of active labour market policies in the various categories provided by OECD.Stat Extracts (training, job rotation and job sharing, employment incentives, and so on).

\section{REFERENCES}

Aghion P. and Howitt P. (1994), Growth and Unemployment, Review of Economic Studies, 61, 477-494.

Allard G. (2005a), Measuring The Changing Generosity Of Unemployment Benefits: Beyond Existing Indicators, Instituto de Empresa Working Paper, WP 05-18.

Allard G. (2005b), Measuring Job Security Over Time: In Search of a Historical Indicator, Instituto de Empresa Working Paper, WP 05-17.

Arpaia A., Curci N. (2010), EU labour market behaviour during the Great Recession, EU Economic Papers, n. 405.

Arpaia A., Kiss A., Turrini A. (2014), Is Unemployment Structural or Cyclical? Main Features of Job Matching in the EU after the Crisis, IZA Policy Paper n. 91.

Bentolila S. and Saint-Paul G. (2003), Explaining Movements in the Labor Share, B.E. Journal of Macroeconomics. 3(1), 1-33.

Blundell R., Bond S.R. (1998), Initial conditions and moment restrictions in dynamic panel data models. Journal of Econometrics, 87, 115-143.

Bloom N., Bond S.R., Van Reenen J. (2001), The dynamics of investment under uncertainty. Institute for Fiscal Studies WP 01/05.

Bonthuis B., Jarvis V., Vanhala J. (2013), What's going on behind the euro area Beveridge curve(s)?, ECB WP n. 1586.

Booth A., Burda M., Calmfors L., Checchi D., Naylor R., Visser J. (2000) What do Unions do in Europe?, A Report, Fondazione Rodolfo DeBenedetti, Milan.

Bruno G.S.F. (2005), Estimation and inference in dynamic unbalanced panel-data models with a small number of individuals, Stata Journal, 5(4), 473-500.

Daniel W. W. and Stilgoe E. (1978) The Impact of Employment Protection Laws, London, Policy Studies Institute.

Destefanis S., Mastromatteo G. (2015), The OECD Beveridge Curve: technological progress, globalisation and institutional factors, Eurasian Business Review, 5(1), 151-172.

Diamond P.A, Şahin A. (2014), Shifts in the Beveridge Curve, Federal Reserve Bank of New York Staff Reports, n. 687. 
Dreher A. (2006), Does Globalization Affect Growth? Evidence from a New Index of Globalization' Applied Economics 38 (10), 1091-1110.

Elsby M.W., Hobijn B., Sahin A. (2010), The Labour Market in the Great Recession, National Bureau of Economic Research Working Paper, n. 15979.

Entorf H. (2003), Do Aggregate Measures of Mismatch Measure Mismatch? A Time Series Analysis of Existing Concepts, Labor and Demography, EconWPA.

Hayakawa, K. (2009), A simple efficient instrumental variable estimator for panel $A R(p)$ models when both $\mathrm{N}$ and $\mathrm{T}$ are large, Econometric Theory, 25, 873-890.

Hobijn B., Şahin A. (2013), Beveridge curve shifts across countries since the Great Recession, IMF Economic Review, 61 (4), 566-600.

ICFTU (1996), The Global Market: Trade Unionism's Great Challenge, ICFTU $16^{\text {th }}$ World Congress, Brussels.

IMF (1996), The Impact of Globalisation on Workers and Their Trade Unions.

Koeniger W., Leonardi M. and Nunziata L. (2007), Labour Market Institutions and Wage Inequality, Industrial and Labour Relations Review, 60 (3), 340-356.

Kumar S. (2008) 'Energy Prices and Induced Technological Progress' Economics Bulletin, 17 (20), 1-14.

Layard R., Nickell S., Jackman R. (1991) Unemployment: Macroeconomic Performance and the Labour Market, Oxford University Press.

Loungani, P. (1986), Oil Price Shocks and the Dispersion Hypothesis, Review of Economics and Statistics, 68(3), 536-539.

Mortensen D.T., Pissarides C.A. (1998), Technological Progress, Job Creation and Job Destruction, Review of Economic Dynamics, 1, 733-753.

Nickell S., Bell B. (1995), The Collapse in Demand for the Unskilled and Unemployment across the OECD, Oxford Review of Economic Policy, 11, 40-62.

Nickell S., Layard R. (1999), Labour Market Institutions and Economic Performance in Ashenfelter O. and Card C. (eds), Handbook of Labor Economics, vol. 3 (Amsterdam: North Holland).

Nickell S., Nunziata L., Ochel W., Quintini G. (2003), The Beveridge Curve, Unemployment and Wages in the OECD from the 1960s to the 1990s, in Aghion P., Frydman R., Stiglitz J. and Woodford M. (eds.), Knowledge, 'Information and Expectations' in Modern Macroeconomics: in honour of Edmund S. Phelps, Princeton University Press, New Jersey, pp. 394-431.

Nickell W. (2006), The CEP-OECD Institutions Data Set (1960-2004), Discussion Paper n.759, Centre for Economic Performance, London School of Economics, November.

OECD (1997), Implementing the OECD Jobs Strategy: Member Countries' Experience.

Pissarides C.A. (1990), Equilibrium Unemployment Theory, Cambridge, MA: MIT Press.

Ordóñez, J., Sala H., Silva J.J. (2011), Oil Price Shocks and Labor Market Fluctuations, Energy Journal, 32 (3), 89-118.

Pissarides C.A., Vallanti G. (2007), The Impact of TFP Growth on Steady-State Unemployment, International Economic Review, 48 (2), 607-640.

Postel-Vinay F. (2002), The Dynamics of Technological Unemployment, International Economic Review, 43, 737-60.

Roodman D. (2009a), How to Do Xtabond2: An Introduction to Difference and System GMM in Stata, Stata Journal, 9 (1), 86-136. 
Roodman D. (2009b), A Note on the Theme of Too Many Instruments, Oxford Bulletin of Economics and Statistics, 71 (1), 135-158.

Sell F.L., Reinisch D.C. (2013), How do the Eurozone's Beveridge and Phillips curves perform in the face of global economic crisis?, International Labour Review, 152 (2), 191-204.

Song L.L., Webster E. (2003), How Segmented Are Skilled and Unskilled Labour Markets? The Case of Beveridge Curves, Australian Economic Papers, 42, 332-345.

Soto M. (2009), System GMM Estimation with a Small Sample, Barcelona Economics WP Series, n. 395.

Thorpe V. (1997), Globalisation and Social Policy, Draft ICEM Position Paper. 


\section{APPENDIX}

Table 1. Expected shifts of the Beveridge Curve: institutional and structural variables

\begin{tabular}{|l|l|}
\hline & Expected Main Impact \\
\hline Unemployment benefits & Outward shift: Nickell et al. (2003) \\
\hline Employment protection legislation & Outward or inward shift: Nickell et al. (2003) \\
\hline Tax wedge & Outward shift: Nickell et al. (2003) \\
\hline Active Labour Market Policies & $\begin{array}{l}\text { Inward shift: Nickell et al. (2003), } \\
\text { Arpaia et al. (2014) }\end{array}$ \\
\hline Bargaining coordination & Inward shift: Nickell et al. (2003) \\
\hline Union density & Outward shift: Nickell et al. (2003) \\
\hline Minimum wage/Median wage & Outward or inward shift: Nickell et al. (2003) \\
\hline Globalisation & $\begin{array}{l}\text { Outward shift (ICFTU, 1996; Thorpe, 1997) or Inward shift (IMF, } \\
\text { 1996; OECD, 1997) }\end{array}$ \\
\hline Technological progress & $\begin{array}{l}\text { Outward shift (creative-destruction effect: Aghion and Howitt, } \\
\text { 1994) or Inward shift (capitalisation effect: Pissarides, 1990; } \\
\text { Mortensen and Pissarides, 1998). }\end{array}$ \\
\hline Oil prices & Outward shift: Nickell et al. (2003) Ordóñez et al. (2011). \\
\hline
\end{tabular}

Table 2. The main variables - some descriptive statistics

\begin{tabular}{|c|c|r|r|r|}
\hline Variable & N & Mean & Min & Max \\
\hline ur & 297 & 5.97 & 0.18 & 0.09 \\
vr & 297 & 0.73 & 3.45 & 2.28 \\
imp/va & 297 & 23.89 & 0.82 & 24.16 \\
r\&d/va & 297 & 7.71 & 105.58 \\
tfp & 297 & 89.32 & 13.01 & 107.39 \\
roilp & 297 & 46.21 & 0.70 & 26.10 \\
UB & 297 & 12.87 & 0.40 & 4.10 \\
EPL & 297 & 2.21 & 18.40 & 5.16 \\
TaxWedge & 287 & 38.67 & 16.80 & 3.04 \\
ALMP & 252 & 0.76 & 1.00 & 83.86 \\
UD & 297 & 43.78 & 0.00 & \\
coordination & 297 & 3.54 & & 0.00 \\
minW & 297 & 0.15 & & \\
\hline
\end{tabular}

Table 3. Globalisation - ratio of total manufacturing imports from non-OECD countries to value added in manufacturing (see text); percentage values for selected years

\begin{tabular}{|c|c|c|c|c|c|}
\hline \multirow{2}{*}{ Country } & \multicolumn{5}{|c|}{ Year } \\
\hline & 1987 & 1997 & 2002 & 2007 & 2012 \\
\hline Australia & 10.16 & 20.19 & 23.66 & 55.7 & 67.38 \\
\hline Austria & 7.93 & 13.44 & 15.46 & 31.35 & 35.89 \\
\hline Finland & 12.88 & 14.44 & 16.22 & 53.61 & 58.16 \\
\hline Germany & 9.54 & 14.15 & 15.29 & 32.96 & 43.12 \\
\hline Norway & 18.41 & 34.84 & 34.34 & 72.8 & 73.5 \\
\hline Portugal & 11.03 & 13.4 & 12.41 & 42.26 & 49.67 \\
\hline Sweden & 10.79 & 11.58 & 13.29 & 31.7 & 38.35 \\
\hline Switzerland & 4.43 & 7.35 & 8.23 & 14.05 & 19.56 \\
\hline United Kingdom & 22.97 & 30.49 & 39.66 & 82.93 & 83.12 \\
\hline
\end{tabular}

Table 4. Technological progress - ratio of R\&D expenditure in manufacturing to value added in manufacturing (see text); percentage values for selected years

\begin{tabular}{|c|c|c|c|c|c|}
\hline \multirow{2}{*}{ Country } & \multicolumn{5}{|c|}{ Year } \\
\hline & 1987 & 1997 & 2002 & 2007 & 2012 \\
\hline Australia & 1.28 & 2.35 & 2.00 & 3.91 & 4.05 \\
\hline Austria & 7.11 & 4.31 & 3.07 & 7.05 & 9.13 \\
\hline Finland & 5.51 & 8.25 & 9.16 & 14.49 & 20.54 \\
\hline Germany & 7.68 & 7.77 & 7.22 & 10.19 & 12.91 \\
\hline Norway & 5.23 & 4.34 & 4.82 & 4.74 & 4.40 \\
\hline Portugal & 4.19 & 6.03 & 6.16 & 6.00 & 6.92 \\
\hline Sweden & 12.57 & 15.17 & 15.56 & 19.28 & 24.41 \\
\hline Switzerland & 6.71 & 7.20 & 5.68 & 5.49 & 5.67 \\
\hline United Kingdom & 8.91 & 8.21 & 10.28 & 13.85 & 12.78 \\
\hline
\end{tabular}



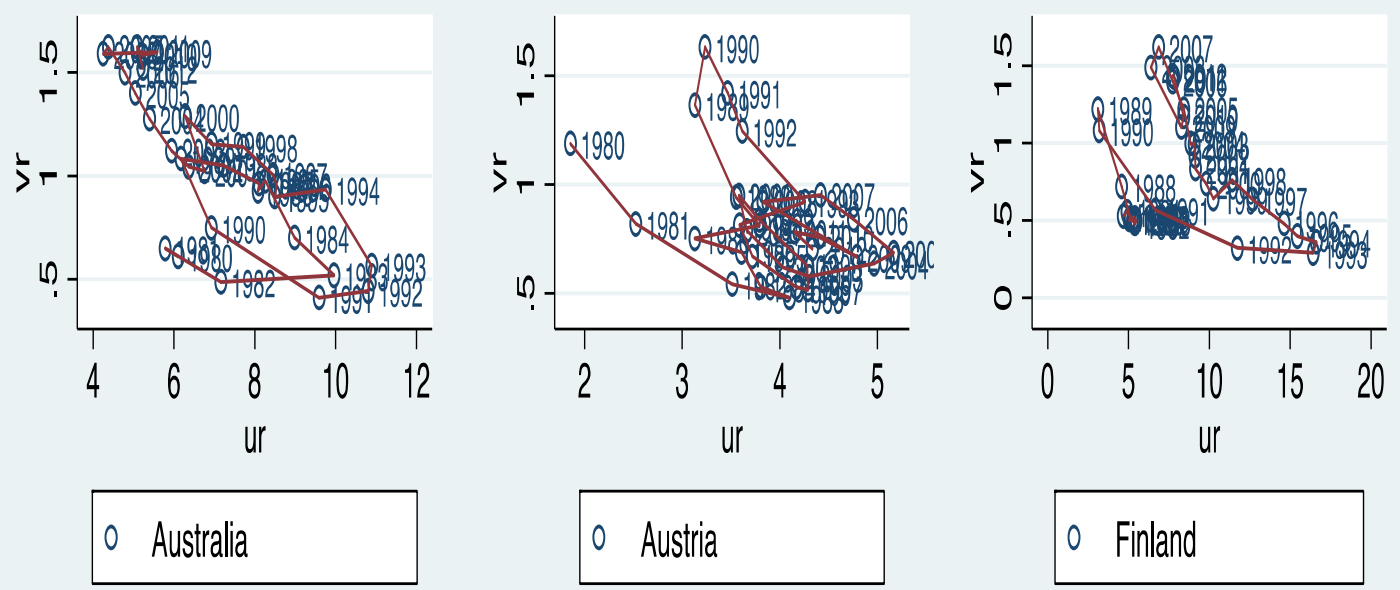

\section{- Austria}
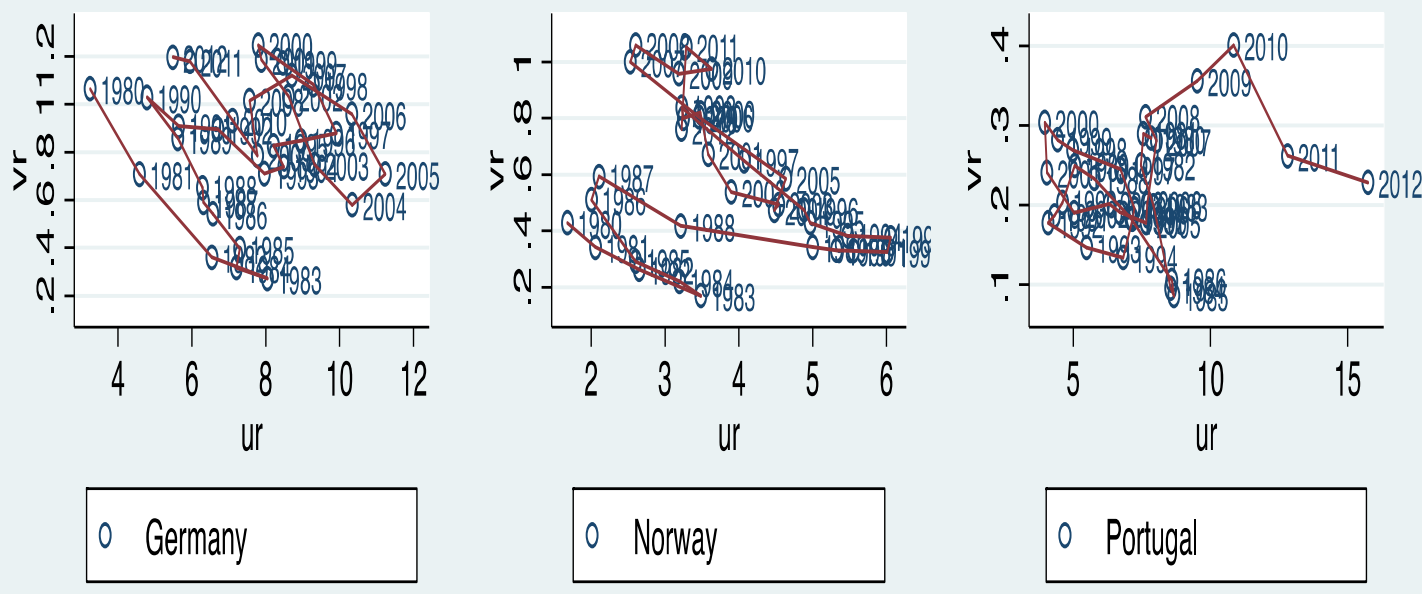

\section{o Norway}

0 Portugal
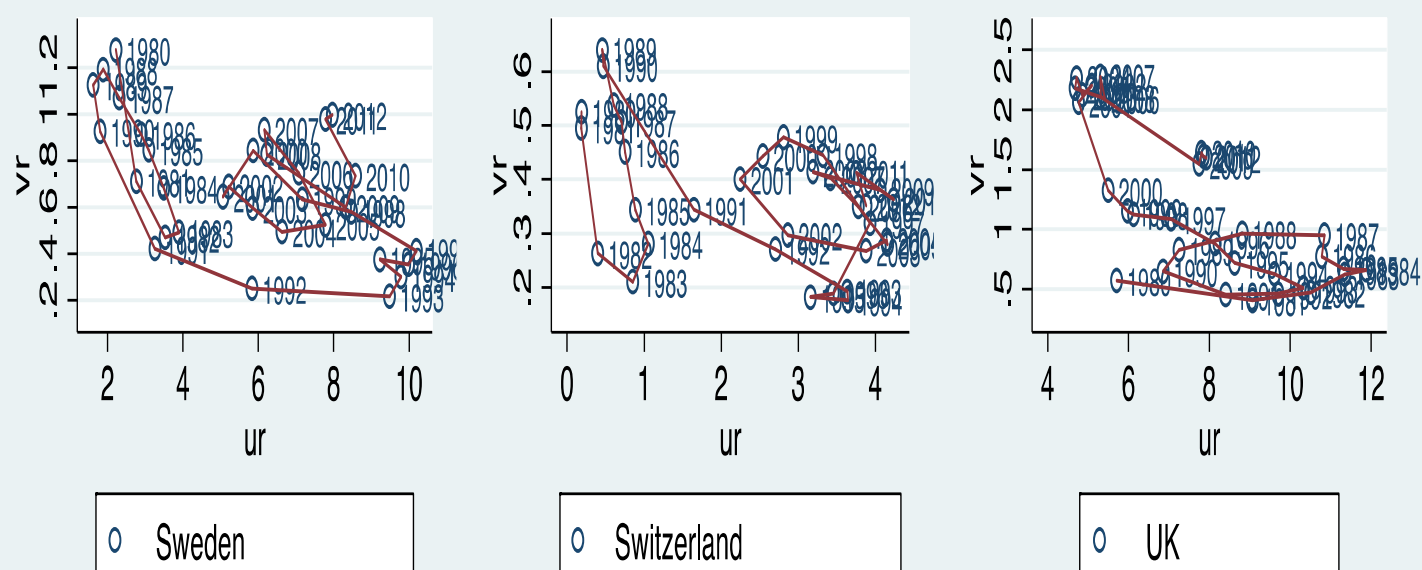

Switzerland

o UK 


\section{Legend of tables}

The dependent variable is always the natural log of the unemployment rate. Technical progress is measured both by $\mathrm{r} \& \mathrm{~d}_{i t}$ a measure of $\mathrm{R} \& \mathrm{D}$ intensity, and $\mathrm{tfp}_{i t}$, an index of total factor productivity; inf $_{i t}$ is the separation rate, defined as the ratio of inflow into unemployment to total employment. Among the $\mathrm{Z}$ variables, $U B$ is the unemployment benefits indicator, $E P L$ the employment protection legislation indicator, $T W$ the total tax wedge, $A L M P$ the active labour market policy indicator (expenditure over GDP), $\min W$ the minimum statutory wage (divided by the median wage). The other variable labels have already been defined in the text. An initial $l$ stands for a variable taken in natural logarithms, a $\_l$ or a 22 termination indicates a first- or second-order lagged variable. Note that the index of $R \& D$ intensity turned out to be more significant if not logged: our reported estimates thus include its linear specification, unlike for $\mathrm{tfp}_{i t}$ and $\mathrm{glob}_{i t}$.

By construction, system GMM allows for country-idiosyncratic effects. We have also included year-specific effects, not shown in the interest of parsimony, in all specifications. Coefficient significances are denoted by stars: * means a p-value $<.1$; ** a p-value $<.05$; *** a p-value $<.01$. The $r h o^{2}$ is the square of the correlation coefficient between the actual and predicted values for the unemployment rate (Bloom et al., 2001, suggest this variable as an indicator of goodness of fit in GMM models). Diagnostics include the Arellano-Bond ( $A B(i))$ test for first, second and third order serial correlation and by the Sargan and Hansen tests of overidentifying restrictions. We provide $\mathrm{p}$-values for all these tests.

\section{Data Sources}

The unemployment rates are taken from OECD Stat Extracts: they are based on OECD standardised rates. The vacancy rates are also taken from OECD Stat Extracts. The separation rate, that is the ratio of inflow into unemployment to total employment, is mainly taken from Nickell et al. (2003), and updated through the OECD Database on Unemployment by Duration (see Nickell et al., 2003, for further details on the calculation of this indicator).

In our preferred globalisation index, total manufacturing imports from non-OECD countries are drawn by the OECD STAN Bilateral Trade Database and International Trade by Commodity Statistics, and value added by the OECD STAN Database for Industrial Analysis. KOF indexes (the overall one, and the sub-index for actual economic flows) come from http://globalization.kof.ethz.ch. We extrapolated the 2012 value for these indexes, that was not available from the original source. More information about them is provided in Dreher (2006).

R\&D intensity uses data for R\&D expenditure taken from the OECD Research and Development Expenditure in Industry Database (2005), and value added by the OECD STAN Database. Total factor productivity is calculated as a Tornqvist index, using gross domestic output, employment, capital stock of the business sector and a smoothed share of labour. The source of the capital stock of the business sector (actually, the private non-residential net capital stock) is the OECD Analytical Database, whereas gross domestic output and employment are 
drawn from OECD.Stat Extracts and the smoothed share of labour from the OECD Unit Labour Costs Dataset.

Oil prices (for the West Texas Intermediate) are taken from the US Energy information Administration. They are converted in each country's currency using exchange rates from OECD.Stat Extracts, and deflated by country-specific consumer price indexes from the same source.

Unemployment benefits are from Allard (2005a), who uses OECD data to build an indicator combining the amount of the subsidy with their tax treatment, their duration and the conditions that must be met in order to collect them. Employment protection legislation series, basically following the OECD methodology, are from Allard (2005b). Both variables are updated using information from OECD.Stat Extracts.

The total tax wedge is equal to the sum of the employment tax rate, the direct tax rate and the indirect tax rate. All three rates rely on information from the OECD National Accounts. The active labour market policy indicator (public expenditure as a percentage of GDP) relies on the series of Labour Market Programmes computed by the OECD. Minimum statutory wage is computed by converting statutory annual minimum wages into hourly wages. Then these wage rates are divided by median hourly wages.

For all the institutional variables the primary data source was Nickell (2006), updated using information from OECD.Stat Extracts.

Table 5. 1985-2007 (specification with Imp/VA)

\begin{tabular}{|c|c|c|c|}
\hline Regressors & Baseline & No TFP & No $R \& D$ \\
\hline lur_1 & $1.24^{\star * *}$ & $1.31^{* * *}$ & $1.33^{* * *}$ \\
\hline lur_2 & $-0.42^{\star * *}$ & $-0.47^{* * *}$ & $-0.47^{\star * *}$ \\
\hline $\operatorname{lvr}$ & $-0.11^{\star \star \star}$ & $-0.10^{\star \star \star}$ & $-0.08^{\star \star *}$ \\
\hline UB_1 & $0.01^{* * *}$ & $0.01^{\star * \star}$ & $0.01^{* * *}$ \\
\hline EPL & $-0.07^{\star * *}$ & $-0.06^{\star \star}$ & $-0.05^{\star * \star}$ \\
\hline TW_1 & $0.01^{* * *}$ & $0.01^{* * *}$ & $0.01^{* * *}$ \\
\hline ALMP_1 & $-0.05^{*}$ & 0.00 & 0.00 \\
\hline $\min W$ & $0.94^{\star \star \star}$ & $0.94^{\star *}$ & $1.12^{\star \star}$ \\
\hline minW_1 & $-0.67^{\star *}$ & $-0.75^{\star \star}$ & $-0.92^{\star *}$ \\
\hline lglob & $0.07^{\star \star \star}$ & $0.09^{\star \star *}$ & $0.05^{* * *}$ \\
\hline r\&d_1 & $0.01^{* * *}$ & $0.01^{* *}$ & \\
\hline ltfp & -0.72 & & -1.21 \\
\hline ltfp_1 & 0.10 & & 0.78 \\
\hline lroilp & $0.48^{\star \star *}$ & $0.54^{\star * \star}$ & $0.58^{* * *}$ \\
\hline lroilp_1 & $-0.46^{* *}$ & $-0.53^{\star \star}$ & $-0.52^{* *}$ \\
\hline $\mathrm{N}$ & 193 & 193 & 193 \\
\hline rho $^{2}$ & 0.961 & 0.956 & 0.957 \\
\hline $\mathrm{AB}(1)$ & 0.024 & 0.036 & 0.015 \\
\hline $\mathrm{AB}(2)$ & 0.179 & 0.122 & 0.244 \\
\hline $\mathrm{AB}(3)$ & 0.542 & 0.637 & 0.595 \\
\hline Sargan & 0.502 & 0.590 & 0.553 \\
\hline Hansen & 0.999 & 0.999 & 0.999 \\
\hline
\end{tabular}


Table 6. 1985-2007 (specification with KOF index for actual economic flows)

\begin{tabular}{|c|c|c|c|}
\hline Regressors & Baseline & No TFP & No $R \& D$ \\
\hline lur_1 & $1.30^{* * *}$ & $1.43^{\star \star \star}$ & $1.57^{* * *}$ \\
\hline lur_2 & $-0.45^{\star \star \star}$ & $-0.52^{\star \star \star}$ & $-0.48^{\star \star \star}$ \\
\hline lvr & $-0.07^{\star * *}$ & -0.02 & -0.04 \\
\hline UB_1 & $0.01^{* \star *}$ & $0.00^{* * *}$ & $0.01^{* * *}$ \\
\hline EPL & $-0.05^{\star \star \star}$ & -0.01 & $-0.03^{*}$ \\
\hline TW_1 & $0.01^{* * *}$ & $0.00^{*}$ & $0.01^{* * *}$ \\
\hline ALMP_1 & $-0.05^{*}$ & -0.01 & -0.02 \\
\hline $\min \mathrm{W}$ & $1.02^{* * *}$ & $1.05^{\star *}$ & $1.14^{* *}$ \\
\hline minW_1 & $-0.78^{\star \star}$ & $-0.90^{\star *}$ & $-0.96^{\star *}$ \\
\hline lglob & -0.04 & 0.13 & 0.06 \\
\hline r\&d_1 & $0.01^{* \star \star}$ & 0.00 & \\
\hline ltfp & -1.19 & & -1.50 \\
\hline ltfp_1 & 0.42 & & 0.99 \\
\hline lroilp & $0.52^{* \star *}$ & $0.58^{* \star}$ & $0.58^{* * *}$ \\
\hline lroilp_1 & $-0.48^{*}$ & $-0.65^{\star \star}$ & $-0.57^{\star *}$ \\
\hline $\mathrm{N}$ & 193 & 193 & 193 \\
\hline $\mathrm{rho}^{2}$ & 0.958 & 0.950 & 0.955 \\
\hline $\mathrm{AB}(1)$ & 0.013 & 0.026 & 0.013 \\
\hline $\mathrm{AB}(2)$ & 0.217 & 0.126 & 0.261 \\
\hline $\mathrm{AB}(3)$ & 0.534 & 0.686 & 0.581 \\
\hline Sargan & 0.500 & 0.677 & 0.592 \\
\hline Hansen & 0.999 & 0.999 & 0.999 \\
\hline
\end{tabular}

Table 7. 1985-2007 (specification with KOF overall index)

\begin{tabular}{|c|c|c|c|}
\hline Regressors & Baseline & No TFP & No $R \& D$ \\
\hline lur_1 & $1.31^{* * *}$ & $1.44^{* * *}$ & $1.38^{* * *}$ \\
\hline lur_2 & $-0.46^{\star \star *}$ & $-0.52^{\star \star \star}$ & $-0.49^{* \star *}$ \\
\hline lvr & $-0.06^{* * *}$ & -0.02 & -0.04 \\
\hline UB_1 & $0.01^{\star \star \star}$ & $0.01^{* * *}$ & $0.01^{* * *}$ \\
\hline EPL & $-0.04^{* \star *}$ & 0.02 & -0.02 \\
\hline TW_1 & $0.01^{* \star *}$ & 0.00 & $0.01^{*}$ \\
\hline ALMP_1 & $-0.05^{*}$ & 0.00 & -0.01 \\
\hline $\min W$ & $1.23^{\star *}$ & $1.27^{* *}$ & $1.36^{* *}$ \\
\hline minW_1 & $-0.97^{\star \star}$ & $-1.09^{* *}$ & $-1.16^{* \star}$ \\
\hline lglob & 0.10 & 0.27 & 0.17 \\
\hline r\&d_1 & $0.01^{* * *}$ & 0.00 & \\
\hline ltfp & -1.02 & & -1.33 \\
\hline ltfp_1 & 0.30 & & 0.85 \\
\hline lroilp & $0.52^{* * *}$ & $0.58^{\star *}$ & $0.58^{\star \star *}$ \\
\hline lroilp_1 & $-0.48^{*}$ & $-0.65^{\star *}$ & $-0.57^{\star *}$ \\
\hline $\mathrm{N}$ & 193 & 193 & 193 \\
\hline rho $^{2}$ & 0.958 & 0.950 & 0.955 \\
\hline $\mathrm{AB}(1)$ & 0.013 & 0.026 & 0.013 \\
\hline $\mathrm{AB}(2)$ & 0.217 & 0.126 & 0.261 \\
\hline $\mathrm{AB}(3)$ & 0.534 & 0.686 & 0.581 \\
\hline Sargan & 0.500 & 0.677 & 0.592 \\
\hline Hansen & 0.999 & 0.999 & 0.999 \\
\hline
\end{tabular}


Table 8. 1985-2012 (specification with Imp/VA). No crisis-specific dummies

\begin{tabular}{|c|c|c|c|}
\hline Regressors & Baseline & No TFP & No $R \& D$ \\
\hline lur_1 & $1.22^{\star * *}$ & $1.29^{\star \star \star}$ & $1.31^{* * *}$ \\
\hline lur_2 & $-0.41^{\star \star \star}$ & $-0.46^{\star \star \star}$ & $-0.46^{\star \star \star}$ \\
\hline lvr & $-0.11^{* * *}$ & $-0.10^{\star * *}$ & $-0.08^{* * *}$ \\
\hline UB_1 & $0.01^{* \star *}$ & $0.01^{* * *}$ & $0.01^{* *}$ \\
\hline EPL & $-0.08^{\star * *}$ & $-0.07^{\star \star \star}$ & $-0.06^{\star \star *}$ \\
\hline TW_1 & $0.01^{* * *}$ & $0.01^{* * *}$ & $0.01^{* * *}$ \\
\hline ALMP_1 & $-0.05^{\star \star *}$ & 0.00 & -0.01 \\
\hline $\min \mathrm{W}$ & $1.10^{\star \star \star}$ & $1.10^{* *}$ & $1.24^{* *}$ \\
\hline minW_1 & $-0.81^{* *}$ & $-0.90^{\star *}$ & $-1.06^{\star \star}$ \\
\hline lglob & $0.07^{* * *}$ & $0.10^{* * *}$ & $0.05^{\star \star *}$ \\
\hline r\&d_1 & $0.01^{* \star \star}$ & 0.00 & \\
\hline ltfp & -1.35 & & -1.53 \\
\hline ltfp_1 & 0.66 & & 1.04 \\
\hline lroilp & $0.47^{\star \star \star}$ & $0.51^{\star \star \star}$ & $0.53^{\star \star \star}$ \\
\hline lroilp_1 & $-0.42^{\star \star *}$ & $-0.48^{\star *}$ & $-0.43^{\star \star}$ \\
\hline $\mathrm{N}$ & 238 & 238 & 238 \\
\hline $\mathrm{rho}^{2}$ & 0.962 & 0.958 & 0.958 \\
\hline $\mathrm{AB}(1)$ & 0.020 & 0.034 & 0.013 \\
\hline $\mathrm{AB}(2)$ & 0.223 & 0.136 & 0.295 \\
\hline $\mathrm{AB}(3)$ & 0.520 & 0.656 & 0.564 \\
\hline Sargan & 0.270 & 0.277 & 0.306 \\
\hline Hansen & 0.999 & 0.999 & 0.999 \\
\hline
\end{tabular}

Table 9. 1985-2012 (specification with KOF index for actual economic flows). No crisis-specific dummies

\begin{tabular}{|c|c|c|c|}
\hline Regressors & Baseline & No TFP & No $R \& D$ \\
\hline lur_1 & $1.29^{* \star *}$ & $1.42^{* * *}$ & $1.36^{\star * *}$ \\
\hline lur_2 & $-0.43^{\text {***}}$ & $-0.51^{* * *}$ & $-0.47^{\star \star \star}$ \\
\hline lvr & $-0.07^{* * *}$ & -0.02 & $-0.05^{\star *}$ \\
\hline UB_1 & $0.01^{\star \star *}$ & $0.00^{\star *}$ & $0.01^{* *}$ \\
\hline EPL & $-0.05^{\star * *}$ & -0.01 & $-0.04^{* *}$ \\
\hline TW_1 & $0.01^{* * *}$ & $0.00^{\star *}$ & $0.01^{\star \star *}$ \\
\hline ALMP_1 & $-0.06^{\star * *}$ & -0.01 & $-0.03^{*}$ \\
\hline $\min W$ & $1.16^{* \star *}$ & $1.23^{\star *}$ & $1.27^{* *}$ \\
\hline minW_1 & $-0.90^{* *}$ & $-1.10^{* *}$ & $-1.10^{* *}$ \\
\hline lglob & 0.00 & 0.18 & 0.09 \\
\hline r\&d_1 & $0.01^{* * *}$ & 0.00 & \\
\hline ltfp & -1.99 & & -2.00 \\
\hline ltfp_1 & 1.17 & & 1.43 \\
\hline lroilp & $0.49^{* \star *}$ & $0.53^{\star \star *}$ & $0.53^{\star \star *}$ \\
\hline lroilp_1 & $-0.44^{* *}$ & $-0.58^{* * *}$ & $-0.48^{* *}$ \\
\hline $\mathrm{N}$ & 238 & 238 & 238 \\
\hline rho $^{2}$ & 0.960 & 0.951 & 0.957 \\
\hline $\mathrm{AB}(1)$ & 0.011 & 0.025 & 0.012 \\
\hline $\mathrm{AB}(2)$ & 0.276 & 0.144 & 0.324 \\
\hline $\mathrm{AB}(3)$ & 0.497 & 0.712 & 0.545 \\
\hline Sargan & 0.288 & 0.407 & 0.370 \\
\hline Hansen & 0.999 & 0.999 & 0.999 \\
\hline
\end{tabular}


Table 10. 1985-2012 (specification with KOF overall index). No crisis-specific dummies

\begin{tabular}{|c|c|c|c|}
\hline Regressors & Baseline & No TFP & No $R \& D$ \\
\hline lur_1 & $1.29^{\star * \star}$ & $1.42^{* \star *}$ & $1.37^{* * *}$ \\
\hline lur_2 & $-0.44^{\star \star *}$ & $-0.52^{\star \star \star}$ & $-0.48^{\star \star \star}$ \\
\hline lvr & $-0.07^{* *}$ & -0.02 & $-0.05^{*}$ \\
\hline UB_1 & $0.01^{* \star *}$ & $0.00^{* * *}$ & $0.01^{* *}$ \\
\hline EPL & $-0.05^{\star \star}$ & -0.01 & $-0.03^{*}$ \\
\hline TW_1 & $0.01^{* \star *}$ & $0.00^{*}$ & $0.01^{* *}$ \\
\hline ALMP_1 & $-0.06^{\star \star *}$ & -0.01 & -0.03 \\
\hline $\min \mathrm{W}$ & $1.18^{* \star *}$ & $1.21^{* * *}$ & $1.28^{\star \star \star}$ \\
\hline minW_1 & $-0.87^{\star *}$ & $-1.01^{\star \star}$ & $-1.08^{\star \star}$ \\
\hline lglob & 0.17 & $0.37^{\star \star \star}$ & 0.19 \\
\hline r\&d_1 & $0.01^{* \star \star}$ & 0.00 & \\
\hline ltfp & -1.56 & & -1.62 \\
\hline ltfp_1 & 0.80 & & 1.09 \\
\hline lroilp & $0.44^{\star * \star}$ & $0.50^{\star *}$ & $0.51^{\star \star \star}$ \\
\hline lroilp_1 & $-0.41^{* *}$ & $-0.52^{\star *}$ & $-0.44^{* *}$ \\
\hline $\mathrm{N}$ & 238 & 238 & 238 \\
\hline $\mathrm{rho}^{2}$ & 0.959 & 0.951 & 0.957 \\
\hline $\mathrm{AB}(1)$ & 0.015 & 0.025 & 0.013 \\
\hline $\mathrm{AB}(2)$ & 0.238 & 0.137 & 0.296 \\
\hline $\mathrm{AB}(3)$ & 0.508 & 0.668 & 0.554 \\
\hline Sargan & 0.203 & 0.546 & 0.283 \\
\hline Hansen & 0.999 & 0.999 & 0.999 \\
\hline
\end{tabular}

Table 11a. Some robustness checks (specification with Imp/VA)

\begin{tabular}{|c|c|c|c|}
\hline Regressors & $\begin{array}{c}\text { No ALMP } \\
(1980-2007)\end{array}$ & $\begin{array}{c}\text { No ALMP } \\
(1980-2012)\end{array}$ & $\begin{array}{l}\text { No Norway } \\
(1985-2012)\end{array}$ \\
\hline lur_1 & $1.21^{* * *}$ & $1.19^{\star \star \star}$ & $1.26^{\star \star \star}$ \\
\hline lur_2 & $-0.38^{* \star *}$ & $-0.36^{\star \star \star}$ & $-0.43^{\star \star \star}$ \\
\hline lvr & $-0.10^{\star * \star}$ & $-0.11^{\star * *}$ & $-0.09^{\star * *}$ \\
\hline UB_1 & $0.01^{* \star *}$ & $0.01^{\star \star \star}$ & $0.01^{* \star \star}$ \\
\hline EPL & $-0.07^{\star \star *}$ & $-0.08^{* * *}$ & $-0.07^{\star * \star}$ \\
\hline TW_1 & $0.01^{* * *}$ & $0.01^{* \star *}$ & $0.01^{* \star *}$ \\
\hline ALMP_1 & & & $-0.05^{\star *}$ \\
\hline $\min W$ & $1.12^{* *}$ & $1.12^{* *}$ & $0.77^{* * *}$ \\
\hline minW_1 & $-0.86^{*}$ & $-0.84^{*}$ & $-0.52^{* *}$ \\
\hline lglob & $0.09^{* *}$ & $0.11^{* *}$ & $0.07^{* \star \star}$ \\
\hline r\&d_1 & 0.01 & $0.01^{*}$ & $0.01^{* \star \star}$ \\
\hline ltfp & 0.40 & -0.75 & $-1.87^{*}$ \\
\hline ltfp_1 & -0.82 & 0.32 & 1.19 \\
\hline lroilp & $0.42^{* * *}$ & $0.43^{* \star *}$ & $0.41^{* \star \star}$ \\
\hline lroilp_1 & $-0.44^{* *}$ & $-0.51^{* *}$ & $-0.30^{\star * *}$ \\
\hline $\mathrm{N}$ & 225 & 270 & 211 \\
\hline rho $^{2}$ & 0.964 & 0.964 & 0.963 \\
\hline $\mathrm{AB}(1)$ & 0.023 & 0.022 & 0.025 \\
\hline $\mathrm{AB}(2)$ & 0.213 & 0.300 & 0.408 \\
\hline $\mathrm{AB}(3)$ & 0.994 & 0.971 & 0.309 \\
\hline Sargan & 0.395 & 0.208 & 0.293 \\
\hline Hansen & 0.999 & 0.999 & 0.999 \\
\hline
\end{tabular}




\begin{tabular}{|c|c|c|c|}
\hline Regressors & $\begin{array}{c}\text { Wth inf } \\
(1980-2007)\end{array}$ & $\begin{array}{c}\text { Wth inf } \\
(1980-2012)\end{array}$ & $\begin{array}{l}\text { Wth inf and crisis } \\
\quad(1980-2012)\end{array}$ \\
\hline lur_1 & $1.10^{\star \star \star}$ & $1.11^{\star \star \star}$ & $1.11^{* * *}$ \\
\hline lur_2 & $-0.36^{\star \star \star}$ & $-0.37^{\star \star \star}$ & $-0.37^{\star \star \star}$ \\
\hline lvr & $-0.18^{\star \star \star}$ & $-0.18^{\star * \star}$ & $-0.18^{\star \star \star}$ \\
\hline $\operatorname{linf}$ & 0.02 & 0.02 & 0.02 \\
\hline UB_1 & $0.01^{\star \star \star}$ & $0.01^{\star \star \star}$ & $0.01^{\star \star *}$ \\
\hline EPL & $-0.13^{\star * \star}$ & $-0.13^{\star * *}$ & $-0.13^{\star \star \star}$ \\
\hline TW_1 & $0.01^{\star \star \star}$ & $0.01^{\star \star \star}$ & $0.01^{\star \star \star}$ \\
\hline ALMP_1 & -0.04 & $-0.04^{*}$ & $-0.04^{*}$ \\
\hline $\min W$ & $0.82^{\star \star \star}$ & $1.02^{\star \star}$ & $1.02^{\star *}$ \\
\hline minW_1 & $-0.52^{*}$ & $-0.73^{*}$ & $-0.73^{*}$ \\
\hline lglob & $0.12^{\star \star \star}$ & $0.12^{\star \star \star}$ & $0.12^{\star \star \star}$ \\
\hline r\&d_1 & $0.01^{\star \star \star}$ & $0.01^{\star \star *}$ & $0.01^{\star \star *}$ \\
\hline $1 \mathrm{tfp}$ & -0.88 & -1.52 & -1.52 \\
\hline ltfp_1 & 0.49 & 1.15 & 1.15 \\
\hline lroilp & $0.50^{\star \star \star}$ & $0.48^{\star \star \star}$ & $0.49^{\star \star \star}$ \\
\hline lroilp_1 & $-0.52^{\star \star \star}$ & $-0.46^{\star * *}$ & $-0.46^{\star * *}$ \\
\hline crisis & & & -0.00 \\
\hline $\mathrm{N}$ & 180 & 225 & 225 \\
\hline rho $^{2}$ & 0.957 & 0.958 & 0.958 \\
\hline $\mathrm{AB}(1)$ & 0.011 & 0.011 & 0.011 \\
\hline $\mathrm{AB}(2)$ & 0.284 & 0.415 & 0.414 \\
\hline $\mathrm{AB}(3)$ & 0.779 & 0.847 & 0.847 \\
\hline Sargan & 0.087 & 0.104 & 0.104 \\
\hline Hansen & 0.999 & 0.999 & 0.999 \\
\hline
\end{tabular}

Table 12a. The Main Results: 1985-2007 (Eq. 1 - Baseline specification with different measures of globalisation)

\begin{tabular}{|c|c|c|c|}
\hline Structural Variables & Imp/VA & $\begin{array}{c}\text { KOF } \\
\text { (actual economic flows) }\end{array}$ & $\begin{array}{c}\text { KOF } \\
\text { (overall) }\end{array}$ \\
\hline Globalisation & $0.07^{\star \star \star}$ & -0.04 & 0.10 \\
\hline$R \& D / V A\left(1^{s t}\right.$ or. lag $)$ & $0.01^{* * *}$ & $0.01^{* \star *}$ & $0.01^{* * *}$ \\
\hline$T F P$ & -0.72 & -1.19 & -1.02 \\
\hline TFP $\left(1^{\text {st }}\right.$ or. lag $)$ & 0.10 & 0.42 & 0.30 \\
\hline Real oil prices & $0.48^{* * *}$ & $0.52^{\star \star}$ & $0.53^{\star *}$ \\
\hline Real oil prices ( $1^{\text {st }}$ or. lag) & $-0.46^{* *}$ & $-0.48^{\star *}$ & $-0.51^{* *}$ \\
\hline
\end{tabular}

Table 12b. The Main Results: 1985-2007 (Eq. 1 - Various specifications with Imp/VA)

\begin{tabular}{|c|c|c|c|}
\hline Institutional Variables & Baseline & No TFP & No $R \& D / V A$ \\
\hline Unemployment Benefit $\left(1^{\text {st }}\right.$ or. lag $)$ & $0.01^{* * *}$ & $0.01^{* * *}$ & $0.01^{* * *}$ \\
\hline Employment Protection Legislation & $-0.07^{* * *}$ & $-0.06^{* *}$ & $-0.05^{\star * *}$ \\
\hline Tax Wedge (1 $1^{\text {st }}$ or. lag $)$ & $0.01^{* \star \star}$ & $0.01^{* * *}$ & $0.01^{* * *}$ \\
\hline$A L M P / G D P\left(1^{\text {st }}\right.$ or. lag $)$ & $-0.05^{\star}$ & 0.00 & -0.00 \\
\hline Min. wage/Median wage & $0.94^{* * *}$ & $0.94^{* \star}$ & $1.12^{* \star}$ \\
\hline Min. wage/Median wage ( $1^{\text {st }}$ or. lag $)$ & $-0.67^{* *}$ & $-0.75^{\star \star}$ & $-0.92^{\star *}$ \\
\hline
\end{tabular}


Table 13a. The Main Results: 1985-2012. (Eq. 1 - Baseline specification with different measures of globalisation)

\begin{tabular}{|c|c|c|c|}
\hline Structural Variables & Imp/VA & $\begin{array}{c}\text { KOF } \\
\text { (actual economic flows) }\end{array}$ & $\begin{array}{c}\text { KOF } \\
\text { (overall) }\end{array}$ \\
\hline Globalisation & $0.07^{\star \star \star}$ & 0.00 & 0.17 \\
\hline$R \& D / V A\left(1^{s t}\right.$ or. lag $)$ & $0.01^{* * *}$ & $0.01^{* * *}$ & $0.01^{* * *}$ \\
\hline$T F P$ & -1.35 & -1.99 & -1.56 \\
\hline TFP $\left(1^{\text {st }}\right.$ or. lag $)$ & 0.66 & 1.17 & 0.80 \\
\hline Real oil prices & $0.47^{\star * *}$ & $0.49^{\star \star *}$ & $0.44^{\star \star \star}$ \\
\hline Real oil prices ( $1^{\text {st }}$ or. lag) & $-0.42^{* * *}$ & $-0.44^{\star *}$ & $-0.41^{\star *}$ \\
\hline
\end{tabular}

Table 13b. The Main Results: 1985-2007 (Eq. 1 - Various specifications with Imp/VA)

\begin{tabular}{|c|c|c|c|}
\hline Institutional Variables & Baseline & No TFP & No R\&D/VA \\
\hline Unemployment Benefit ( $1^{\text {st }}$ or. lag) & $0.01^{* * *}$ & $0.01^{* * *}$ & $0.01^{* *}$ \\
\hline Employment Protection Legislation & $-0.08^{* * *}$ & $-0.07^{\star *}$ & $-0.06^{* * *}$ \\
\hline Tax Wedge (1 $1^{\text {st }}$ or. lag) & $0.01^{* * *}$ & $0.01^{* * *}$ & $0.01^{* * *}$ \\
\hline$A L M P / G D P\left(1^{s t}\right.$ or. lag $)$ & $-0.05^{\star \star *}$ & 0.00 & -0.01 \\
\hline Min. wage/Median wage & $1.10^{\star * *}$ & $1.10^{\star *}$ & $1.24^{* *}$ \\
\hline Min. wage/Median wage ( $1^{\text {st }}$ or. lag) & $-0.81^{* *}$ & $-0.90^{* *}$ & $-1.06^{\star *}$ \\
\hline
\end{tabular}

Table 14. The Impact of the Crisis: Eqs. $2 b$ and $2 c-$ Baseline specification with Imp/VA. (Standalone slope dummy for each institutional variable in turn in Eq. 2c)

\begin{tabular}{|c|c|c|c|c|c|c|}
\hline & Eq. 2b & Eq. 2c & Eq. 2c & Eq. 2c & Eq. 2c & Eq. 2c \\
\hline & & $U B \_1$ & $E P L$ & $T W_{-} 1$ & $A L M P_{-} 1$ & $\begin{array}{c}\min W \\
\min W_{-} 1\end{array}$ \\
\hline $\begin{array}{l}\text { crisis }{ }^{*} \text { Australia } \\
\text { crisis }{ }^{*} \text { Austria } \\
\text { crisis }{ }^{*} \text { Finland } \\
\text { crisis }{ }^{*} \text { Germany } \\
\text { crisis }{ }^{*} \text { Norway } \\
\text { crisis*Portugal } \\
\text { crisis }{ }^{*} \text { Sweden } \\
\text { crisis }{ }^{*} \text { Switzerl'd } \\
\text { crisis } * U K\end{array}$ & $\begin{array}{l}0.0244 \\
-0.0660^{\star \star \star} \\
-0.0025 \\
-0.1160^{\star \star \star} \\
-0.0060 \\
0.0389 \\
0.0068 \\
0.1033^{\star \star \star} \\
0.0322 \\
\end{array}$ & & & & & \\
\hline $\begin{array}{l}U B \_1 \\
\text { crisis*UB_1 }\end{array}$ & $0.01^{* * *}$ & $\begin{array}{l}0.01^{* \star *} \\
0.00\end{array}$ & & & & \\
\hline $\begin{array}{l}E P L \\
\text { crisis*EPL }\end{array}$ & $-0.10^{* * *}$ & & $\begin{array}{l}-0.07^{\star * \star} \\
-0.03\end{array}$ & & & \\
\hline $\begin{array}{l}T W_{-} 1 \\
\text { crisis } * T W_{-} 1\end{array}$ & $0.01^{* * *}$ & & & $\begin{array}{l}0.01^{* \star *} \\
-0.01^{* \star *}\end{array}$ & & \\
\hline $\begin{array}{l}A L M P_{-} 1 \\
\text { crisis*ALMP_l }\end{array}$ & $-0.07^{\star \star \star}$ & & & & $\begin{array}{l}-0.08^{\star * *} \\
-0.11^{*}\end{array}$ & \\
\hline $\begin{array}{l}\min W \\
\min W_{-} 1 \\
\text { crisis }{ }^{*} \min W \\
\text { crisis }{ }^{*} \text { min } W_{-} 1\end{array}$ & $\begin{array}{l}0.83^{\star \star *} \\
-0.58^{\star \star}\end{array}$ & & & & & $\begin{array}{l}0.90^{\star \star *} \\
-0.68^{\star *} \\
-0.81 \\
0.89\end{array}$ \\
\hline$r h o^{2}$ & 0.966 & 0.963 & 0.963 & 0.965 & 0.964 & 0.963 \\
\hline
\end{tabular}


Table 15. The Impact of the Crisis: Eq. 2d - Baseline specification with Imp/VA.

(Standalone slope dummy for each institutional variable in turn)

\begin{tabular}{|c|c|c|c|c|c|}
\hline & $U B \_1$ & $E P L$ & $T W_{-} 1$ & $A L M P \_1$ & $\begin{array}{c}\min W \\
\min W \_1\end{array}$ \\
\hline $\begin{array}{l}\text { crisis*Australia } \\
\text { crisis }{ }^{*} \text { Austria } \\
\text { crisis }{ }^{*} \text { Finland } \\
\text { crisis }{ }^{*} \text { Germany } \\
\text { crisis }{ }^{*} \text { Norway } \\
\text { crisis }{ }^{*} \text { Portugal } \\
\text { crisis }{ }^{*} \text { Sweden } \\
\text { crisi }{ }^{*} \text { Switzerl'd } \\
\text { crisis }{ }^{*} \text { UK }\end{array}$ & $\begin{array}{l}0.0618^{\star \star} \\
-0.0387 \\
-0.0555 \\
-0.1858^{\star \star \star} \\
0.0164 \\
-0.0034 \\
-0.0115 \\
0.0854^{\star} \\
0.1467\end{array}$ & $\begin{array}{l}-0.1270 \\
-0.0400^{\star} \\
0.0213 \\
-0.1034^{\star \star *} \\
0.1215 \\
0.2235^{\star *} \\
0.0102 \\
0.0019 \\
-0.0933\end{array}$ & $\begin{array}{c}0.0844 \\
-0.1178 \\
-0.0316 \\
-0.1858 \\
0.0009 \\
0.0434^{*} \\
-0.0290 \\
0.1923 \\
0.0586\end{array}$ & $\begin{array}{l}0.1112^{*} \\
-0.0856^{\star * *} \\
-0.0610^{\star} \\
-0.1608^{\star * *} \\
0.0192 \\
0.0457^{\star} \\
-0.0864 \\
0.1302^{\star * *} \\
0.1000^{\star}\end{array}$ & $\begin{array}{l}0.0653 \\
-0.1019^{\star * \star} \\
0.0121 \\
-0.1117^{\star \star \star} \\
-0.0563 \\
0.0436 \\
0.0617^{\star} \\
0.0501^{*} \\
0.0594\end{array}$ \\
\hline $\begin{array}{l}U B \_1 \\
\text { crisis*UB_l }\end{array}$ & $\begin{array}{l}0.01^{* \star *} \\
0.01\end{array}$ & & & & \\
\hline $\begin{array}{l}E P L \\
\text { crisis*EPL }\end{array}$ & & $\begin{array}{l}-0.10^{\star \star \star} \\
-0.17\end{array}$ & & & \\
\hline $\begin{array}{l}\text { TW_1 } \\
\text { crisis } * T W_{-} 1\end{array}$ & & & $\begin{array}{l}0.01^{\star \star \star} \\
0.00\end{array}$ & & \\
\hline $\begin{array}{l}\text { ALMP_l } \\
\text { crisis*ALMP_l }\end{array}$ & & & & $\begin{array}{l}-0.08^{* * *} \\
0.22\end{array}$ & \\
\hline $\begin{array}{l}\min W \\
\min W \_1 \\
\text { crisis*min }{ }^{*} \text { min } \\
\text { crisis*minW_1 }\end{array}$ & & & & & $\begin{array}{l}0.81^{\star \star \star} \\
-0.55^{\star \star} \\
0.70 \\
1.89 \\
\end{array}$ \\
\hline$r h o^{2}$ & 0.966 & 0.966 & 0.966 & 0.966 & 0.966 \\
\hline
\end{tabular}



Ministry of Economy and Finance

Department of the Treasury

Directorate I: Economic and Financial Analysis

Address:

Via XX Settembre, 97

00187 - Rome

Websites:

WWW.mef.gov.it

www.dt.mef.gov.it/it/

e-mail:

dt.segreteria.direzione1@tesoro.it

Telephone:

$+390647614202$

$+390647614197$

Fax:

$+390647821886$
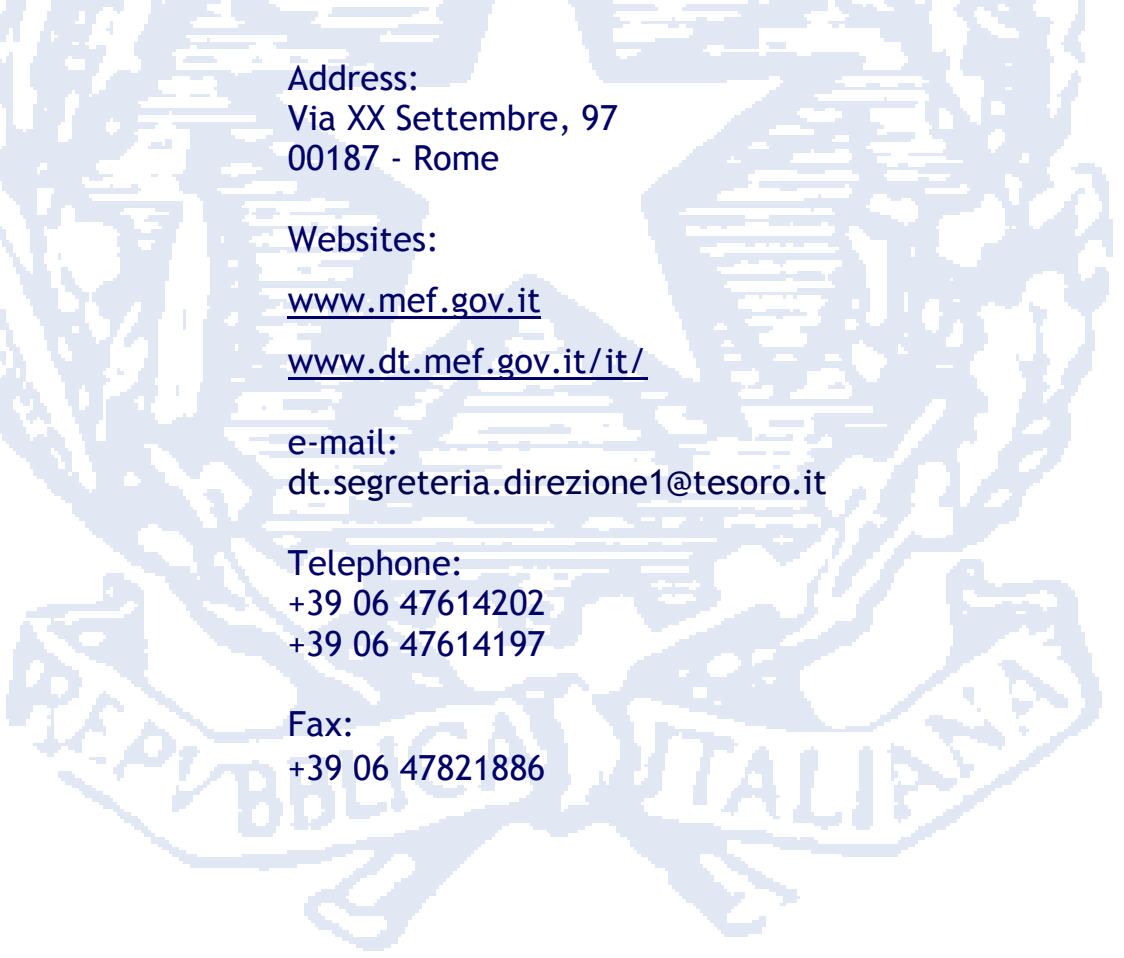